\title{
超高真空試料搬送導入装置を用いた リチウムイオン電池材料の分析
}

\author{
小林英一 $1,2, *$ ・朝倉大輔 3,4 - 細野英司 ${ }^{3,4} \cdot$ 田中秀吉 ${ }^{2}$ \\ ${ }^{1}$ 佐賀県立九州シンクロトロン光研究センター 寀841-0005 佐賀県鳥栖市弥生が丘八丁目 7 番地 \\ 2 国立研究開発法人 情報通信研究機構 未来 ICT 研究所 遥 651-2492 兵庫県神戸市西区岩岡町岩岡 588-2 \\ ${ }^{3}$ 国立研究開発法人 産業技術総合研究所 正305-8568 茨城県つくば市梅園 1-1-1 \\ ${ }^{4}$ 産業技術総合研究所・東京大学 先端オペランド計測技術オープンイノベーションラボラトリ \\ 嶫 277-8581 千葉県柏市柏の葉 5-1-5
}

（2020 年 2 月 15 日受付；2020 年 5 月 26 日掲載決定）

\begin{abstract}
Analysis of Lithium-ion Battery Materials Using a Portable Ultrahigh-vacuum Sample Transfer Vessel
Eiichi KobaYashi $^{1,2, *}$, Daisuke AsaKura ${ }^{3,4}$, Eiji Hosono $^{3,4}$ and Shukichi TANAKA ${ }^{2}$

${ }^{1}$ Kyushu Synchrotron Light Research Center, 8-7 Yayoigaoka, Tosu, Saga 841-0005

${ }^{2}$ Advanced-ICT Research Institute, National Institute of Information and Communications Technology,

588-2 Iwaoka, Iwaoka-cho, Nishi-ku, Kobe, Hyogo 651-2492

${ }^{3}$ National Institute of Advanced Industrial Science and Technology (AIST), 1-1-1 Umezono, Tsukuba, Ibaraki 305-8568

${ }^{4}$ AIST-UTokyo Advanced Operando-Measurement Technology Open Innovation Laboratory, 5-1-5 Kashiwanoha, Kashiwa, Chiba 277-8581
\end{abstract}

(Received February 15, 2020 ; Accepted May 26, 2020)

\begin{abstract}
We analyzed the lithium-ion battery material $\mathrm{LiNi}_{0.5} \mathrm{Mn}_{1.5} \mathrm{O}_{4}$ electrode using a portable vacuum transfer vessel. When investigating the chemical state of carbon by X-ray photoelectron spectroscopy, it is important that the battery material is not exposed to the atmosphere. In addition, it was found that when investigating the chemical state of fluorine, it is necessary to analyze not only the effect of the reaction with atmospheric components, but also the deterioration due to irradiation with the X-ray. When the sample is transported in an argon atmosphere for a long time, the oxygen concentration in the transfer vessel increases due to degassing from the sample and the vessel, and the sample surface becomes contaminated.
\end{abstract}

KEYWORDS : lithium-ion battery, $\mathrm{LiNi}_{0.5} \mathrm{Mn}_{1.5} \mathrm{O}_{4}$ (LNMO), polytetrafluoroethylene (PTFE), ultrahigh-vacuum sample transfer vessel, photoelectron spectroscopy

\section{1.は じめ に}

リチウムイオン電池はパソコンなどの小型機器から自 動車, 航空機や宇宙探査機まで幅広い分野で利用されて おり, 高性能化を目指し様々な電池材料の探索や開発が 行われている。電池材料の高性能化には, 既存材料に対 する結晶構造解析や電子状態解析による反応機構の解明

†2019 年日本表面真空学会学術講演会（2019 年 10 月 28 日～ 30 日）にて発表

*E-mail : kobayashi@saga-ls.jp
が必須であり, 後者においては硬 X 線領域の吸収分光 に加えて超高真空を必要とする軟 X 線領域の分光の利 用が広がってきている。リチウムイオン電池に用いられ る有機電解液は大気中に含まれる水, 酸素, 二酸化炭素 などに対して反応性が高いため，充放電を施した電極等 の軟 $\mathrm{X}$ 線領域の分光測定においては大気非暴露の測定 環境が必要となる。

多くの場合, 充放電させた電池をアルゴン䨌囲気下の グローブボックスで分解し, 測定対象の電極を取り出し て分析装置の試料ホルダーに固定して搬送し, 軟 X 線 
領域の分光測定を行う。近年は測定技術の進歩に伴い, 電池を分解せずに充放電下の “オペランド観察”が可能 となり, 電極材料の酸化還元反応が調べられている ${ }^{1 \sim 33}$ 。 我々はこれまで大気非暴露の測定を可能にする試料搬 送導入装置を開発してきた ${ }^{4,5)}$ 。さらに精度の高い分析 をするため, 乾電池で駆動可能な小型のイオンポン プ6)を搭載した可搬型超高真空試料搬送導入装置を開発 した ${ }^{7,8)}$ 。本装置を用いることで, 試料表面の炭素酸化 物や酸素の吸着による污染は大きく抑制される9)。その ため, 従来の搬送技術では高精度に分析できなかった材 料表面の炭素や酸素の分析が行えるようになった。本装 置を用いた分析はコンタミネーションの影響を強く受け る表面分析手法に扔いて非常に有効となる。

本研究では, 可搬型超高真空試料搬送導入装置を用い てリチウムイオン電池電極表面の炭素種の分析を光電子 分光法で試みたので報告する。電極表面の炭素種として 結着剤のポリテトラフルオロエチレン (PTFE), ポリフ ッ化ビニリデン (PVDF), スチレン・ブタジエン共重合 体 (SBR), 導電助剂のカーボンブラックや電解液など があげられる。結着剤は正極活物質や負極活物質を結着 させて電極板を作成するため使用されるものである。電 極材料に加えて, これらの結着剤や導電助剂も電池の性 能を大きく左右する構成物質であり, 充放電による劣化 反応の解明や，充放電によって電極表面に形成される Solid Electrolyte Interface（SEI）と呼ばれる被膜の形成過 程の解明は電池開発において重要である。そのため, 電 極表面層に存在する炭素の結合状態をより精確に知るこ とが必要であり, 大気との反応性を確認しておくことは 重要である。

\section{2. 実}

験

\section{1 試料}

試料には正極材料の $\mathrm{LiNi}_{0.5} \mathrm{Mn}_{1.5} \mathrm{O}_{4}$ （LNMO）を用いた。 LNMO を導電助剤の Super-P Li, 結着剤の PTFE と, 重 量比 $75: 20: 5$ の割合で混合し合材電極とした。この合 材電極を作用極として, 金属 $\mathrm{Li}$ の対極および参照極と, 有機電解液の $1 \mathrm{M} \mathrm{LiClO} /$ /EC-DEC（エチレンカーボネー ト（EC）、ジエチルカーボネート（DEC）をを組み合わせ て3 極のセルを作成した。 $100 \mathrm{~mA} / \mathrm{g}$ の電流密度で定電流 充電を行い, 光電子分光測定には $5 \mathrm{~V}$ まで充電した試料 を用いた。

\section{2 可搬型超高真空試料搬送導入装置による搬送}

試料作製後, アルゴン雲囲気のグローブボックスにて 光電子分光装置のホルダーの試料固定面にペースト状の 試料を押さえ板とネジで固定した。試料表面の清浄化処 理はなにも行っていない。試料の固定に要した時間はお
よそ 30 分程度であり, 作業直前のグローブボックスの 露点は約 $-48{ }^{\circ} \mathrm{C}$ 程度であり, 作業後は $-44{ }^{\circ} \mathrm{C}$ 程度で あった。そのホルダーは, グローブボックスに取り付け られた搬送用のチャンバーに移動した。チャンバーは夕 ーボ分子ポンプで排気した後, 試料は連結された可搬型 超高真空試料搬送導入装置内に移送し, 真空中で封じ た。その後, 試料を封入した搬送導入装置をチャンバー から切り離した。その際の試料搬送導入装置内の圧力は 約 $4 \times 10^{-6} \mathrm{~Pa}$ であった。そして, 光電子分光装置が装 備された分析装置の準備チャンバーまで移動し接続し た。移動後, 搬送導入装置を接続した準備チャンバー内 を真空引きし, その圧力が約 $3 \times 10^{-6} \mathrm{~Pa}$ 以下に達した ことを確認した後, 試料を搬送導入装置から準備チャン バーに移動した。移動直前の試料搬送導入装置内の圧力 は約 $1 \times 10^{-5} \mathrm{~Pa}$ であった。試料が搬送導入装置内に封 入されていた時間は掞よそ 36 時間であった。大気に曝 した試料は準備チャンバーを窒素でパージ後, 約 10 分 程，大気中に放置して作製した。

\section{3 光電子分光装置}

$\mathrm{X}$ 線光電子分光 (XPS) 装置は佐賀県立九州シンクロ トロン光研究センター（SAGA-LS）の BL12 に設置され た ULVAC-PHI 社製の ESCA1600（特型）を用いて行っ た。励起光源は非単色化 $\mathrm{AlK} \alpha$ 線（1486.6 eV）を使用し た。エネルギー軸のキャリブレーションは, 真空中でア ルゴンイオンスパッタリングした $\mathrm{Au} 4 \mathrm{f}, \mathrm{Ag} 3 \mathrm{~d}, \mathrm{Cu} 2 \mathrm{p}$ の光電子スペクトルを測定し, 過去に報告されているピ 一クの正確な結合エネルギー值と比較することで行なっ た。

\section{3. 実験結果と考察}

Fig. 1 （a）は $5 \mathrm{~V}$ まで充電した LNMO 電極を可搬型 超高真空試料搬送導入装置により搬送し, 直後に測定し た $\mathrm{C} 1 \mathrm{~s}$ 光電子スペクトルである。スペクトルは主に四 つのピークから成って押り, 結合エネルギー約 $284.4 \mathrm{eV}$ のピークは C-C, 約 $285.7 \mathrm{eV}$ のピークは C-O, 約 288.0 $\mathrm{eV}$ のピークは $\mathrm{C}=\mathrm{O}$, 約 $291.6 \mathrm{eV}$ のピークは $\mathrm{C}-\mathrm{F}_{2}$ 由来 のものと考えられる ${ }^{10 \sim 13)}$ 。 $\mathrm{C}-\mathrm{F}_{2}$ は結着剂の PTFE から のシグナル, C-C は PTFE, 導電助剤や電解液からのシ グナル, $\mathrm{C}-\mathrm{O}$ P $\mathrm{C}=\mathrm{O}$ は電解液や SEI からのシグナルと 考えられる。以上のことから, 電極表面の炭素種として 様々な構成物質があるが，結着剤の PTFE のシグナルは 他の物質からのシグナルと区別して情報を得ることがで きることがわかる。

Fig. 1 (b) は大気に曝した際の C $1 \mathrm{~s}$ 光電子スペクト ルである。Fig. 1 （b）から大気に曝すことで電極表面に 炭素酸化物である $\mathrm{C}-\mathrm{O}$ P $\mathrm{C}=\mathrm{O}$ が増加していることが 


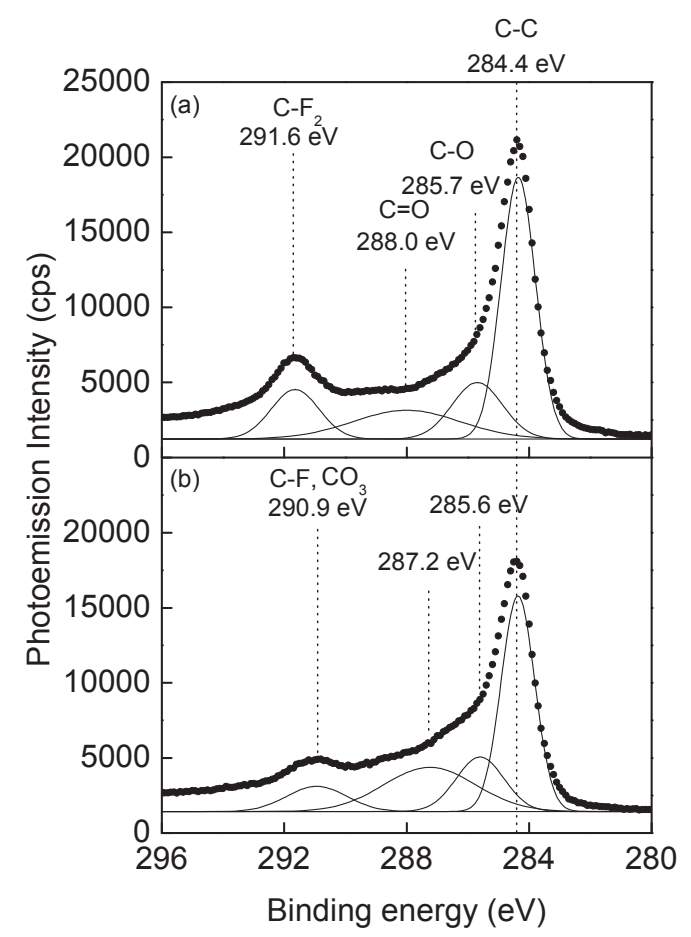

Fig. 1. C 1s photoelectron spectra of LNMO electrode brought in measurement chamber (a) with the vacuum transfer vessel and (b) after exposure to air.

わかる。また, 結合エネルギー約 $291.6 \mathrm{eV}$ のピーク強 度が減少し, 新たな約 $290.9 \mathrm{eV}$ のピークが現れた。こ のピークは電極表面の $\mathrm{LiOH}$ と大気中の $\mathrm{CO}_{2}$ が反応して $\mathrm{LiCO}_{3}$ が生成され, $\mathrm{CO}_{3}$ 由来のピークが現れた可能性が ある ${ }^{(4)}$ 。或いは大気曝露により結着剤の PTFE からフッ 素が脱離したため C-F 由来のピークが現れた可能性が ある。このことから, 電極は大気に曝すと本来の電極反 応と無関係な炭素種が生じてしまい, グローブボックス の利用や大気非暴露の搬送は必須であることがわかる。 また, フッ素の脱離の原因としてXPS 測定の場合, 励 起光源の $\mathrm{AlK} \alpha$ 線照射による効果も含まれていると考え られる。X線照射によりフッ素を脱離させた PTFEの

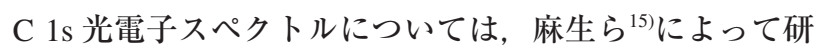
究されている。彼らはX 線照射時間が長くなると C $1 \mathrm{~s}$ 光電子スペクトルの $284.2 \mathrm{eV}$ と $291.7 \mathrm{eV}$ の間に新たな ピークが生成されることを報告している。本研究で新た に観測された約 $290.9 \mathrm{eV}$ のピークはそのピークに対応 する可能性がある。

フッ素が脱離したことは Fig. 2 からもわかる。Fig. 2 (a) は $5 \mathrm{~V}$ まで充電した LNMO 電極を真空で搬送し, 直後に測定したものであり, Fig. 2（b）は大気に曝した 際の $\mathrm{F} 1 \mathrm{~s}$ 光電子スペクトルである。スペクトルのピー ク強度は大気に曝すことで咸少していることから, フッ

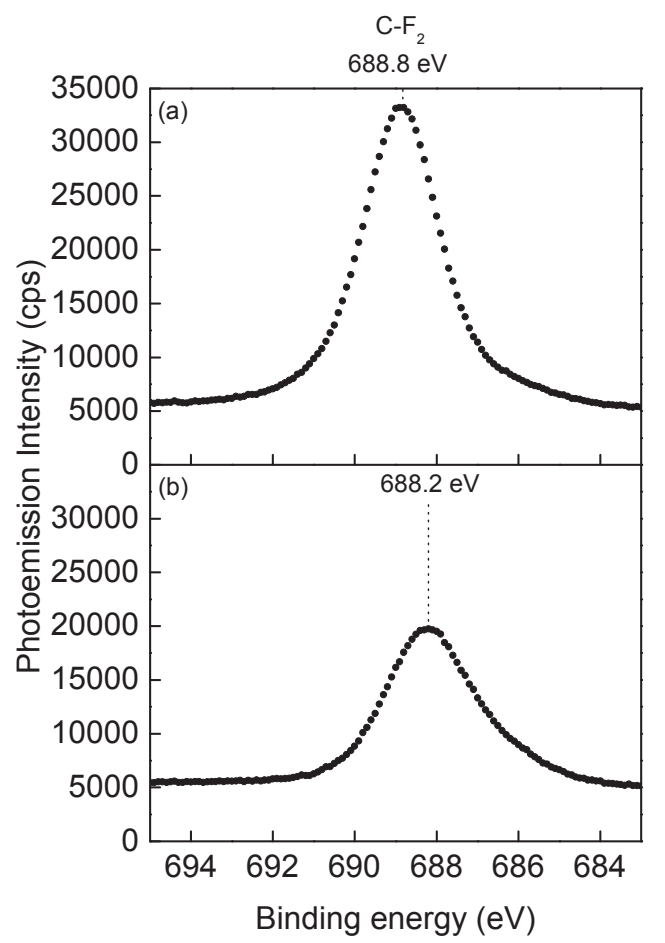

Fig. 2. F 1s photoelectron spectra of LNMO electrode brought in measurement chamber (a) with the vacuum transfer vessel and (b) after exposure to air.

素の脱離が確認できる。ピークの結合エネルギーは約 $688.8 \mathrm{eV}$ から約 $688.2 \mathrm{eV}$ にシフトしており, フッ素の 化学結合状態の変化或いはフッ素が脱離したことによる 表面電荷の変化の可能性がある ${ }^{15)}$ 。

Fig. 3 (a) は $5 \mathrm{~V}$ まで充電した LNMO 電極を真空で 搬送し, 直後に測定したものであり, Fig. 3 (b) は大気 に曝した際の O 1s 光電子スペクトルである。Fig. 3 (a) では，スペクトルは主に二つのピークから構成されてお り, 結合エネルギー約 $529.7 \mathrm{eV}$ のピークは金属酸化物, 約 $533.0 \mathrm{eV}$ のピークは有機物由来のものと考えられる。 大気に曝すと Fig. 3（b）から結合エネルギー約 533.5 $\mathrm{eV}$ のピークが主になり, 炭素酸化物である $\mathrm{C}-\mathrm{O}$ 由来の ものであると考えられる。この結果は, Fig. 1 の C 1s 光電子スペクトルの結果と一致している。

多くの場合，アルゴン雲囲気下で試料を搬送している が, 長時間封じて搬送した場合, 時間が経つにつれて試 料や容器からの脱ガスにより搬送容器内の酸素濃度など が高くなり, 充電した活性の高い試料の表面は污染され てしまう可能性がある。本装置は小型イオンポンプが酸 素を含む主な残留ガスを排気し, 超高真空で搬送できる のでより精確な表面の状態の分析を可能にしている。 Fig. 4 は $5 \mathrm{~V}$ まで充電した LNMO 電極をアルゴン䨌囲 気で搬送（約 $-38{ }^{\circ} \mathrm{C}$ 程度の露点で試料搬送導入装置内 


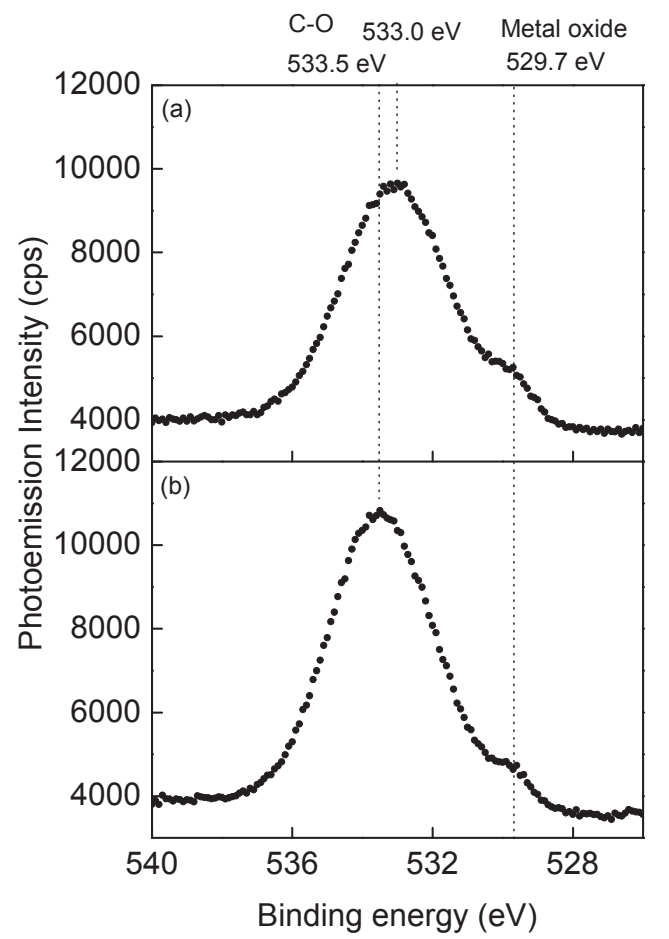

Fig. 3. O 1s photoelectron spectra of LNMO electrode brought in measurement chamber (a) with the vacuum transfer vessel and (b) after exposure to air.

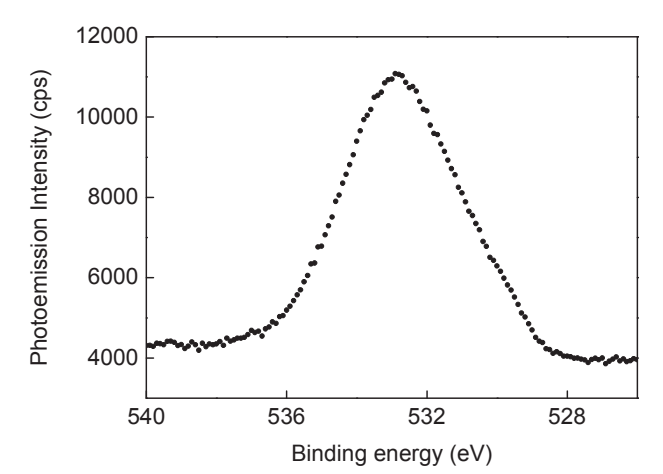

Fig. 4. O 1s photoelectron spectra of LNMO electrode brought in measurement chamber with the transfer vessel in argon atmosphere.

にておよそ 38 時間 45 分保持）した後, 超高真空下で測 定した $\mathrm{O} 1 \mathrm{~s}$ 光電子スペクトルである。Fig. 3 (a) のス ペクトルと比較すると, 金属酸化物由来のピークが顕著 に観測されなくなり, 電極表面は酸化が進行しているこ とがわかる。このことからもできるだけ早く超高真空環 境で保持することが重要であることがわかる。また，ア ルゴン雲囲気のグローブボックス内での作業も同様に試 料やグローブボックスからの脱ガスにより試料表面が污 染されてしまう可能性があるので，できるだけ短い時間 で試料ホルダーへの試料の取付けと搬送作業を行う必要
がある。加えて, 試料表面の污染の程度はグローブボッ クス内の残留ガスにも依存するので, 露点も低くしてお く必要がある。

\section{4. まと め}

本研究では可搬型超高真空試料搬送導入装置を用いた 搬送によるリチウムイオン電池材料の LNMO 電極を光 電子分光法により調べた。その結果, 炭素の電子状態観 測には大気非暴露環境が必須であることが確認できた。 また, フッ素の電子状態観測には大気中の成分との反応 による影響だけでなく，XPS 測定においては Fig. 1（b) より $\mathrm{C}^{-} \mathrm{F}_{2}$ 由来のピークが減少し, $\mathrm{C}-\mathrm{F}$ 由来のピークが 現れ，Fig. 2 (b) よりフッ素のピーク強度が弱くなった ことから X 線照射による劣化も考慮して分析する必要 があることがわかった。さらに, 長時間アルゴンガスで 封じて搬送した場合, 試料や容器からの脱ガスにより搬 送容器内の酸素濃度などが高くなり, 試料表面が污染さ れてしまう可能性があるので, 超高真空下での搬送が重 要であることがわかった。

軽元素からなる結着剤や導電助剂は電極内部の構成物 質であり, 充放電による劣化反応の解明や SEI の形成過 程の解明は電池開発において重要である。軽元素の分析 はコンタミネーションとの区別や測定対象としない箇所, 例えばステンレス製の試料ホルダー表面に吸着している CO からのシグナルと Fig. 1 (a) のC 1s や Fig. 2 (a) の $\mathrm{O} 1 \mathrm{~s}$ 光電子スペクトルの $\mathrm{C}-\mathrm{O}$ 由来のピークとの区別が つきにくいため, 得られたスペクトル等の解釈が困難に なる場合もある。今後, より精密で精確な分析を行うに は, 試料の処理方法や搬送技術も高度化していく必要が あると思われる。

\section{文献}

1) D. Asakura, E. Hosono, H. Niwa, H. Kiuchi, J. Miyawaki, Y. Nanba, M. Okubo, H. Matsuda, H. Zhou, M. Oshima and Y. Harada : Electrochem. Commun. 50, 93 (2015).

2) D. Asakura and E. Hosono : Electrochemistry 84, 529 (2016).

3) D. Asakura, Y. Nanba, M. Okubo, H. Niwa, H. Kiuchi, J. Miyawaki, M. Oshima, E. Hosono and Y. Harada : Phys. Chem. Chem. Phys. 21, 26351 (2019).

4) E. Kobayashi, J. Meikaku, T. Okajima and H. Setoyama : Japanese Patent No. 5234994. (in Japanese).

5) E. Kobayashi, J. Meikaku, H. Setoyama and T. Okajima : J. Surf. Anal. 19, 2 (2012). (in Japanese).

6) S. Tanaka : Japanese Patent No. 4831548. (in Japanese).

7) E. Kobayashi, S. Tanaka and T. Okajima : J. Vac. Soc. Jpn. 59, 192 (2016). (in Japanese).

8) E. Kobayashi, S. Tanaka and T. Okajima : J. Vac. Soc. 
Jpn. 60, 139 (2017). (in Japanese).

9) E. Kobayashi and S. Tanaka : Vac. Surf. Sci. 62, 551 (2019). (in Japanese).

10) C. Lee, S. Kim, J. Jang and S. Lee : Sci. Rep. 7, 13797 (2017).

11) D. Yang, A. Velamakanni, G. Bozoklu, S. Park, M. Stoller, R.D. Piner, S. Stankovich, I. Jung, D.A. Field, C.A. Ventrice Jr. and R.S. Ruoff : Carbon 47, 145 (2009).

12) S. Piperno, H. Cohen, T. Bendikov, M. Lahav and I.
Lubomirsky : Phys. Chem. Chem. Phys. 14, 5551 (2012).

13) C. Vasile, M.C. Baican, C.M. Tibirna, C. Tuchilus, D. Debarnot, E. Pâslaru and F. Poncin-Epaillard : J. Phys. D : Appl. Phys. 44, 475303 (2011).

14) T. Yoon, N. Chapman, D.M. Seo and B.L. Lucht : J. Electrochem. Soc. 164, A2082 (2017).

15) 麻生昭弘, 北田隆行, 田沼繁夫 : J. Surf. Anal. 1, 255 (1995). 